\title{
The Spanish Long-Term Care System: Deployment, Restructuring Processes and Future Challenges
}

\author{
Esther Albesa Jové \\ Universidad de Barcelona - albesaje@gmail.com
}

\begin{abstract}
This paper examines in-depth the case of the Spanish long-term care system (LTCS) restructuring processes and its shortcomings owing to the 2008 economic 'shock', and its future challenges. It focuses on four analysis dimensions: nature and principles, access, services provision and organisation, management and funding. And three levels: workers and recipes of public services, legislative reforms, and social and institutional impact of the crisis. The outcomes display a double process of expansion-contraction: the first, during the system's deployment (2008-10) followed by a second phase (2010-17) centered on the cost-containment, the reinforcement of the system's family-based nature, and a process of

a re-familiarisation and re-commodification. Despite that the Dependency Law contributed to a 'paradigmatic change' by modifying the nature of the former care policy, from the second phase onwards the system's shortcomings became obvious due to a shortfall of resources and organisational issues. The mechanisms aimed at downsizing the system were restricting the access criteria and delaying the system's deployment, and curtailing the provision of services and payment of cash benefits. Moreover, the widespread provision in cash-benefits entailed a re-familiarisation and a re-commodification of the new Spanish LTCS contributing to the proliferation of an unregulated care market.
\end{abstract}

Keywords: Spanish long-term care system, austerity measures, economic crisis impact.

\section{O Sistema Espanhol de Cuidados de Longo Prazo: Desdobramento, Processos de Reestruturação e Desafios Futuros}

\section{Resumo}

Este artigo examina em profundidade o caso do processo de reestruturação do sistema espanhol de cuidados de longo prazo (LTCS) e as suas deficiências devido ao "choque" económico de 2008, e os seus desafios futuros. Centra-se em quatro dimensões de análise: natureza e princípios, acesso, prestação e organização de serviços, gestão e financiamento. E três níveis: trabalhadores e receitas dos serviços públicos, reformas legislativas, e impacto social e institucional da crise. Os resultados mostram um duplo processo de expansão-contração: o primeiro, durante a implantação do sistema (2008-10), seguido 


\section{The Spanish Long-Term Care System:}

\section{Deployment, Restructuring Processes and Future Challenges}

de uma segunda fase (2010-17) centrada na contenção de custos, no reforço da natureza familiar do sistema e num processo de re-familiarização e de re-mercadorização. Apesar de a Lei da Dependência ter contribuído para uma "mudança paradigmática" ao modificar a natureza da anterior política de cuidados, a partir da segunda fase as deficiências do sistema tornaram-se óbvias devido a uma escassez de recursos e de questões organizacionais. Os mecanismos destinados a reduzir o sistema estavam a restringir os critérios de acesso e a atrasar a implantação do sistema, bem como a reduzir a prestação de serviços e o pagamento de benefícios pecuniários. Além disso, a ampla provisão de benefícios pecuniários implicou uma re-familiarização e uma re-mercadorização do novo LTCS espanhol, contribuindo para a proliferação de um mercado de cuidados não regulamentado.

Palavras-chave: Sistema espanhol de cuidados de longo prazo, medidas de austeridade, impacto da crise económica.

\section{INTRODUCTION}

The Long-term care (LTC) is a broad concept, largely used in scientific and international literature. This implies an autonomy restriction prompted by any kind of disability, along with a dependency situation in which individuals need care for carrying out daily life activities (DLA). Despite the fact that this situation can be given in any stage of life, it is the elderly who already have and will require a higher level of supports in the future, given that dependency is directly associated with agerelated disabling chronic illnesses, and loss of physiological functions. Thus, fragility, chronic illness or disabilities can lead to limiting conditions in various spheres in the DLA, and LTC has become an established term covering the heterogeneous range of 'care' provisions that can help and support people in these dire situations. Services can include nursing care, personal assistance, domestic help, and social support, but also supervision and care management (Österle \& Rothgang, 2010). In this vein, the Organisation for Economic Co-operation and Development (OECD) has defined LTC as the care of people who need support in multiple facets over a long period of time which refers to DLA, such as bathing, dressing, entering and leaving their home carried out by relatives, friends, unqualified caregivers or nurses (OECD, 2011).

Over the last years LTC has become the forefront of the welfare state. Many countries have implemented new LTC policies that move away from traditional characteristics of fragmentation and assistance-based models. The novelty of LTC as a welfare 
state (WS) issue has encouraged thinking beyond traditional development paths, while developments remain deeply rooted in the traditional principles and ideas of particular WS models or regimes (Esping-Andersen, 1990, 2000; Österle \& Rothgang, 2010). LTC involves a high degree of complexity due to its extensive repertoire of actors, multilevel structure of management and resources (Bettio \& Plantenga, 2004).

Since the 1990s, unlike the classic social policies (health care, pensions, unemployment and education), European LTCS have been one of the social policy sectors that expanded the most (Pavolini \& Ranci, 2013). Often this spread of LTCS in postindustrial European societies has been attributed to the so-called New Social Risks (NSR). Sociodemographic changes and progressive aging population driven by the scientific and medical advances would have contributed to the extension of life expectancy, despite of people suffering from highly incapacitating chronic diseases. From this point of view, changes would be considered the outcome of the LTC systems' adaptation to the new societal needs. The transformations within family structures and current demands of the labour market would also explain the inability of families to deal with the care needs of their dependent members. Integration of women into the labour market (traditionally in charge of family care) has radically contributed to the modification of the traditional informal support structure, provoking a situation of informal care crisis (Urgerson, 2005; Bettio, Simonazzi, \& Villa, 2006). Yet, along with this increase in care needs, and the downsizing of informal care supports, we also encounter restructuring processes such as: re-familiarisation, re-commodification, costs containment or de-institutionalisation of care which have been undertaken by governments in order to tackle financial strains, and to ensure economic sustainability.

Most of the studies on Spanish LTCS are centred on the features of the former system or the transition from a residual social care system to the current model (since the Act 39/2006 came into force) rooted in a universal right. Little is known about the changes during the system's deployment, and what have been the restructuring processes occurred within the Spanish LTCS owing to the economic crisis. Because of that, the main purpose of this article is to discuss in-depth the development and the restructuring processes occurred in the Spanish LTCS from its inception, converging with the 2008 economic crisis until 2017. This paper is structured in five sections. The first contains the main theoretical concepts related to the 'social care' dimension, also the relevant research and literature related to changes and restructuring processes within the European LTC framework. The second section focuses on the Span- 


\section{The Spanish Long-Term Care System:}

Deployment, Restructuring Processes and Future Challenges

ish LTC policy sector, demographic trends, family and the financial and economic crisis impact. In the third, the methodology framework is showcased. The remaining sections concentrate on the assessment of changes and restructuring processes following the three analysis levels and dimensions, discussion of findings, and the setting out of conclusions.

\section{LONG-TERM CARE WITHIN THE EUROPEAN CONTEXT}

From the point of view of the welfare mix, Anttonen \& Sipilä (2005) distinguish three principal care providers: the public sector, the market (private sector), and the family and voluntary sector. Care can also be analysed on the basis of two major areas of provision: formal and informal. The former is defined as the care provided by public or private labour contract with individuals, family or caregivers. Whilst informal care is carried out by the family or social environment, without any kind of economic compensation, or despite being covered by some kind of public transfer (such as subsidies for supporting non-professional caregivers), this one is not subject to any formal labour contract (OECD, 2011). In addition, there are three main provision types: (a) direct financing by means of cash benefit payments or tax relief, and indirect financing, consisting in subsidies that may be received by the caretakers, the dependent person, the family or an institution; (b) service provision which includes a large number of services and providers (public, semi-public, private or non-profit organisation), and an array of objectives, cost and regulatory models; (c) work permits such as flexible and reduced working hours, or free disposal hours (Daly, 2012). However, Daly also points out that all these types of provision, which aimed at encouraging care work at home, contribute to care re-familiarisation and re-commodification by providing incentives for job creation, labour market expansion, and by increasing the care of people within the family environment.

On an international scale scholars have also defended specific care regimes when it comes to elucidate institutional care settings. Daly \& Lewis (2000) classify care arrangements according to whether the obligation of care provision is assumed by the state or by the family (de-familiarisation). From this point of view, these authors assemble four care regimes: the Nordic, the continental European, the liberal welfare and the non-caring states. The nature of the first model is universal; meaning that the state provides care to all people in need. Mainly through services in order to mini- 
mise the family burden and to hold the state responsible for care. This type of regime is usually represented by countries which uphold a dual bread-winner family-model which includes Sweden, Finland or Denmark. The continental European regime (Germany, France and Belgium) holds a contributory-based nature. The cornerstone of this regime is the promotion of care through the family and voluntary organisations financed by public funding. In the liberal regime (well-known as assistancebased model) Ireland and the United Kingdom (UK) are the most striking cases in Europe. In these latter countries there is a significant shortage of public services, and territorial differences in provision (Esping-Andersen, 1990). Lastly, in the non-caring state regimes, a feature of Southern European countries (Italy, Greece, Portugal and Spain), there has historically been a significant lack of services, and the care responsibility falls upon the family, especially the women. This last regime has also been called implicit family-based model in which public policy provision has focused on economic transfers to reinforce family care commitments (Leitner, 2003).

Pavolini \& Ranci (2008) have evaluated public innovation and mechanisms used to reform LTCS over the last three decades. The main reforms discerned by these authors have been the emergence of a new private care market and the bolstering of the users' purchasing power through economic benefits in order to purchase private services. Thus, the governments have led to a shift in the balance between publicprivate provision whilst transferring the management responsibility from central to local level, hand in hand with cost-containment by shifting responsibility from the institutional (public) to the family (private) sphere, and by promoting the de-institutionalisation of care. In order to explain the type of changes, Pavolini \& Ranci (2013), following Hall (1993), have highlighted a set of mechanisms with ensuing first and second-order changes (rather than paradigmatic or third-order changes aimed at modifying the basic objectives and principles of social care policy) meaning a broader use and modification of social policy instruments such as: raising contributions or co-payment to beneficiaries; introducing new requirements; reducing benefits; restricting access among other options. These authors also warn that the increase of cash benefits and the re-orientation of provision towards the family environment (ageing in place) have entailed a re-familiarisation in which the responsibility of care is transferred from the public sector to the family setting (Esping-Andersen, 2000).

An array of studies focuses on the balance between family, market and state (welfare mix) under socioeconomic constraints and political changes where the market has become predominant. The main goal of this re-commodification process 


\section{The Spanish Long-Term Care System:}

Deployment, Restructuring Processes and Future Challenges

(Pierson, 2001) is to displace care coverage from the public realm towards the market sector (Daly \& Lewis, 2000; da Roit \& Le Bihan, 2010; Rodriguez Cabrero, 2011). For these scholars the cost containment process, as a consequence of financial and economic strains, would have also pursued to avoid entries in institutions (de-institutionalisation) and thus, lowering the cost of care. This de-institutionalisation policy that has put emphasis on care in or by the community rather than within an institution is a long-term trend across South European countries (Deusdad, Lev, Pace, \& Vell, 2017). Because of the political concerns about increasing care needs and longterm sustainability of current care regimes, the most high-income economies are seeking to minimise the use of institutional care, expanding formal home-care whose consequences are the growing role of family care-givers (Kodate \& Timonen, 2017). According to the World Health Organisation (WHO), this de-institutionalisation has not always materialised in the best interest of older people, mostly because ageing in place requires services and facilities located close to the homes of the elderly, which have to be affordable and known to potential users by means of clear information (WHO, 2007). Moreover, in the Mediterranean WS the strains, put on families, and the low public coverage have led to a rapid growth of an informal care market, made up of female immigrants over the last decades. The introduction of the cash for care and the free choice in countries like Spain, where there are no care labour regulations, have favoured a submerged care market, mainly in the elderly sector integrated by female immigrants, and connected to the new care work global dynamics (Martínez, 2006; Oso \& Parella, 2012).

According to Spasova et al. (2018), drawn from a comparative LTC policy analysis between 2008-2018 and carried out by the European Social Policy Network (ESPN) in 35 European countries, all the countries faced significant LTCS challenges over the last ten years. There are four challenges common to all: adequate access to LTC provision, quality of home-care and residential care, employment of informal care, and financial sustainability of the national systems. Access and adequacy are linked to the stunted growth of publicly funded formal LTC services; quality of care is at risk due to the significant increase in demand and lack of quality control in many countries; employment of carers, women in particular who are often informal carers and may need to quit their jobs due to caring responsibilities; and financial sustainability due to population ageing and increasing public spending on LTC. The authors have also identified three broad trends during the last ten years: the readjustment of the LTC policy mix, namely the move-away from residential care towards home care 
and community-care; measures addressing financial sustainability whilst introducing budgetary restrictions, in particular during the crisis' period; and reforms aimed at improving the access and affordability of provisions including increased LTC funding, improving eligibility conditions and benefit levels, tackling interinstitutional and territorial LTC fragmentation, and recognition and improvement of the status of informal carers.

In the framework of the COST Action 1102 "Social services, welfare state and places 2012-2015” Deusdad, Comas-d’Argemir \& Dziegielewski (2016) have analysed the LTC restructuring process in Spain linked to the impact of the economic crisis on social policies. These scholars have explored the social service strategies to deal with the increase in care needs as well as community-based responses. They concluded that fueled by the economic crisis, so many relatives were unable to cope with the care burden. Services became more limited, thus services available were not enough to reduce the pressure of caring activities on the family caregivers which could lead to stress and, in some cases, to elder abuse. The economic crisis also affected social workers' working conditions, placing great pressure on them to solve generalized social problems. Another important feature highlighted was the increase in marketisation where citizens have to fully pay or co-pay for care services.

Economic crisis of 2008 also had an inequal impact over European countries and their LTCS. Spain and England represent the countries in which the crisis hit the most, for their principal economic sectors were tightly linked to the crisis (larger financial and real estate market sectors). On the contrary, the crisis had a smaller impact on those countries with a larger productive sector, high levels of exports and production linked to great investments in research and development, as the cases of Sweden and Germany. So England and Spain, where the crisis had a more dramatic impact, their LTCS have also endured major contractions, whereas Germany and Sweden's LTCS did not contract or contracted less. Between 2008-17 in these countries a further tendency has been the widespread expansion of legal LTC rights (except in England). But, in reality, only the German LTCS has benefited from a real and overall expansion (Jové, 2020).

Over the last years LTC policy has also become part of the European political agenda. In 2003 the Council and the European Commission drafted the first reports on LTC in which, along with health and public pension systems, LTC policies are analysed within the framework of the European Social Model (Consejo de Europa, 1998; Council of the European Commission, 2003). The research work, conducted 


\section{The Spanish Long-Term Care System:}

Deployment, Restructuring Processes and Future Challenges

by social researchers on this subject, have predicted that the European Social Model has faced a complex process of convergence in recent years. According to Rodriguez Cabrero (2007) the tension between convergence in social protection policies in the countries and their respective "path dependency" or national traditions is particularly reflected in LTC policies. In 2017, given the effects of the 2008 economic crisis and the difficulties the European Union citizens have been confronted with, the European Union Council, European Parliament and European Commission (2017) signed off the so-called European Pillar of Social Rights during a social summit.

The European Pillar of Social Rights (EPSR) represents a wider effort to build up a more inclusive and sustainable growth model by improving Europe's competitiveness and making it a better place to invest, create jobs and foster social cohesion. The EPSR contains 20 key rights that are organised into three main categories targeted at solving the acute challenges of the present: unemployment, poverty and discrimination. Special attention is drawn to the specific problems of the young, older people and the disabled. In view of this document, these challenges can be tackled by securing well-functioning labour markets and welfare systems. Specifically these $20 \mathrm{key}$ rights and principles provided for by the document are: rights to education and longlife-learning, gender equality, equal opportunities, active support for employment and good employment conditions, social dialogue, work-life balance, work environment, childcare, social protection, unemployment benefits, minimum income, old age income and pensions, health care, inclusion of people with disabilities, long term care, housing and assistance for homeless, as well as access to essential services (water, sanitation, energy, transport, financial services and digital communications). Regarding old age income and pensions, EPSR claims that workers and the self-employed in retirement have the right to a pension commensurate to their contributions and an adequate income ensuring life with dignity; that women and men shall enjoy equal opportunities to acquire pension rights. And everyone has the right to affordable LTC services of good quality, in particular home-care and community-based services (Council of the European Union, 2017).

\section{PUBLIC INNOVATION WITHIN THE SPANISH LTC POLICY SECTOR}

South European countries have been considered to represent a differentiated model from the rest of the European WS as it showcases a particular Mediterranean 
or Latin modernisation pattern (Ferrera, 1996). One of its main features has been the shortage of public family care supports, due to the high family solidarity level that has inhibited the care responsibilities from the state and handed them over to the family sphere. Equally the Spanish LTCS has historically been characterised by a high feminisation of care levels (Flaquer, 2002; Rodríguez Cabrero, 2009). The Act 39/2006 on the Promotion of Personal Autonomy and Care for Dependent Persons (LAPAD, for its acronym in Spanish) was considered as an undeniable advance of social rights in Spain. Previously there was no comprehensive regulation on LTC in the Spanish State. An array of fragmented sectorial social policies coexisted; some still have a contributory and subjective nature, and others were assistance-based; only accessible on the grounds of the government budgetary availability, and connected to the applicants' economic capacity. Until the end of 2006 this pre-reform LTCS was structured into two formal care levels: The Social Security System and the Personal Social Services System. The LAPAD is the outcome of a long-term process which after a broad debate crystallises in 2003 with the reform of the Toledo Agreement, the development of the White Paper on Care of Dependency by the Institute for the Elderly and Social Services (IMSERSO, 2005), and the agreements signed by the political and social forces in 2005 (Marbán, 2012).

The Care Act 39/2006 enactment represented the coverage and the institutionalisation of dependency risk in Spain. It defines dependency as "the permanent state in which people who, for reasons of age, illness or disability and the lack of physical or mental autonomy, require considerable support in their DLA" (p. 9). At least, from a theoretical (legally) approach, this Act represents a 'paradigmatic' or 'thirdorder change' (Hall, 1993) in which there has been a modification of the fundamental objectives and important changes within the 'nature' of social policy with respect to the previous one; because the LTCS goes from an assistance-based model for people, which lacks financial resources, towards a universal-based care model based on a subjective right. The Law regulates the conditions for guaranteeing the equality in the exercise of the universal and subjective right to promote personal autonomy and care for all dependent citizens, irrespective of the region in Spain in which they live. The subjective right (according to the Decree 142/2010 of Social Services) states that public authorities have to provide care for all dependent people.

The universality of the right is translated into the access to services and benefits for the entire dependent population, regardless of their economic capacity. Therefore, the subjective right of access can be demanded by law if not complied with. The 


\section{The Spanish Long-Term Care System:}

Deployment, Restructuring Processes and Future Challenges

principles inspiring the Act are: comprehensive and personalised care; prevention; rehabilitation; social and mental stimulation; autonomy; keeping the person within his/her family environment, and preferential attention towards people with higher degrees of dependency. The LAPAD and the Royal Decree 174/2011 determine three dependence degrees: moderate (I), severe (II) and high dependence (III). The regional governments are competent for the assessment by means of specialised territorial teams. The allocated resources are subject to: the type of resource, the geographical availability and the waiting lists within every region, especially regarding residential services. Benefits might be of economic or service nature. The highest regulatory body is the Territorial Council of the System for the Autonomy and Attention of Dependence. The Central Government is liable to warrant the subjective right of care for all dependent people; regions are responsible for planning, coordinating, evaluating, inspecting and managing the system and the resources. Municipalities are competent in the elaboration and follow-up of the individual care plan.

\subsection{Demographic trends and challenges}

LTC need is growing in line with population ageing. Due to the disability among older people, the loss of family ties and growing female labour-market participation entail the growing need for care for frail and disabled seniors. This growth in older age cohorts is one of the main drivers of increased demand for LTC across OECD countries, and policy concern is also framed within the pressures arising from ageing societies. Less than $1 \%$ of the global population was aged over 80 years in 1950. In OECD countries the share of those aged eighty and over is expected to increase from $4 \%$ in 2010 to nearly $10 \%$ in 2050 (OECD, 2011). OECD has also highlighted that the demographic trends entail a hose of implications for government, economic growth and welfare. The total average on elderly population, people aged 65 and over across OECD countries (37 members) in 2018 was $17.2 \%$. As is evidenced by figure 1, Southern European countries have been one of the highest affected by the demographic changes. The population over age 65 in 2018 in Italy was 22,7\%, 21,9\% in Greece, $21,7 \%$ in Portugal and 19,3\% in Spain (OECD, 2020). These figures will probably increment in the coming years because of low birth rates and an increase in life expectancy which will imply the need of more services and social supports to maintain elderly people independence. 


\section{Figure 1}

Total average on elderly population across OECD countries in 2018

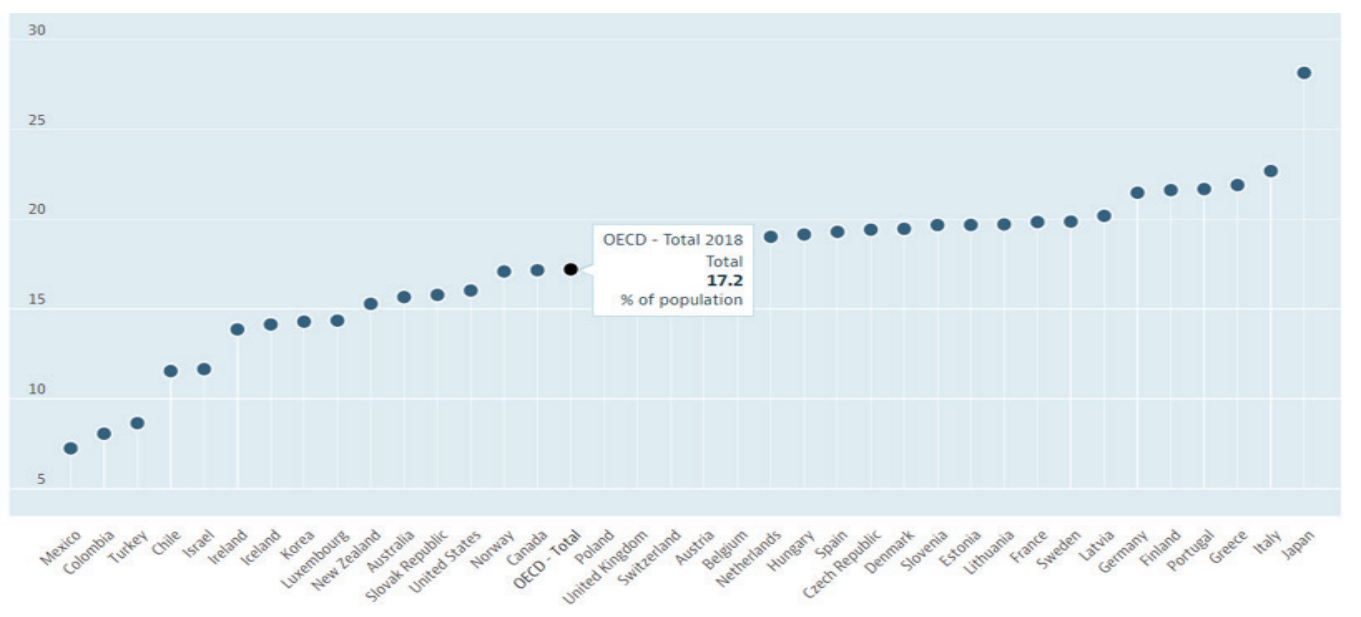

Sources: Elderly population OECD (2020).

In 2016 life expectancy at birth on average across OECD countries, which measures how long people would live on average, based on a given set of age-specific death rates, reached 80.6 years; an increase of more than ten years since 1970. Life expectancy at birth now exceeds 80 years in two-thirds of OECD countries, with Japan, Spain and Switzerland at the top of the ranking. The gains in longevity can be attributed to a number of factors, including an improved lifestyle, better working conditions and education, as well as progress in health care. Life expectancy at birth also varies by gender; at 83.3 years for women compared to 77.9 years for men in 2016 on average across OECD countries. This also depends on the socio-economic status of a person. Higher education levels do not only provide the means for improving the socio-economic conditions in which people live and work, but may also promote the adoption of healthier lifestyles and facilitate access to appropriate health care. On average, among 25 OECD countries women and men with the highest level of education at age 30 can expect to live four to seven years longer than people with the lowest level of education (OECD, 2019).

According to the Spanish National Statistic Institute (INE, 2016) the population structure by age shows a slump in the groups under 20 years. That would fall from $20 \%$ of the total population in 2016 to $15 \%$ in 2066 . As well as the group of age between 20-64 that would decrease from $61 \%$ to $50 \%$ in the very same period. Conversely, a 


\section{The Spanish Long-Term Care System:}

Deployment, Restructuring Processes and Future Challenges

significant growth in the number of people within the 65-and + age group is expected (as we can see on table 1).

\section{Table 1}

Structure of the population by age in Spain between 1959-2066

\begin{tabular}{cccccccc}
\hline Age group & \multicolumn{2}{c}{1959} & \multicolumn{2}{c}{2016} & \multicolumn{2}{c}{2066} & Var. 2016-2066 \\
\hline$<20$ & - & - & 9,2 & $20 \%$ & 6,4 & $15 \%$ & $-5,0 \%$ \\
$20-64$ & - & - & 28,0 & $61 \%$ & 20,4 & $50 \%$ & $-11 \%$ \\
+64 & $8,1 \%$ & 8,7 & $19 \%$ & 14,1 & $35 \%$ & $+16 \%$ \\
\hline
\end{tabular}

Source: compiled by the author from INE projections (2016).

As figure 2 shows, population ageing in Spain is also clear. The average on life expectancy at birth was 83,58 years in 2019: 80,86 years for men and 86,22 years for women (INE, 2020a). Related to the total Spanish population, in January 2020, population aged $65+$ over was $19,58 \%$ and $6,03 \%$ was the oldest, aged $80+$ over (INE, $2020 \mathrm{~b}$ ). Thus, in conjunction with the increase of the ageing and over-ageing population, a higher level of care supports will be required in a near future in order to meet people's care needs due to disabling chronic illnesses, and the loss of physiological age-associated functions (for instance Alzheimer disease).

\section{Figure 2}

Population projections by age and gender in Spain (1959-2066)

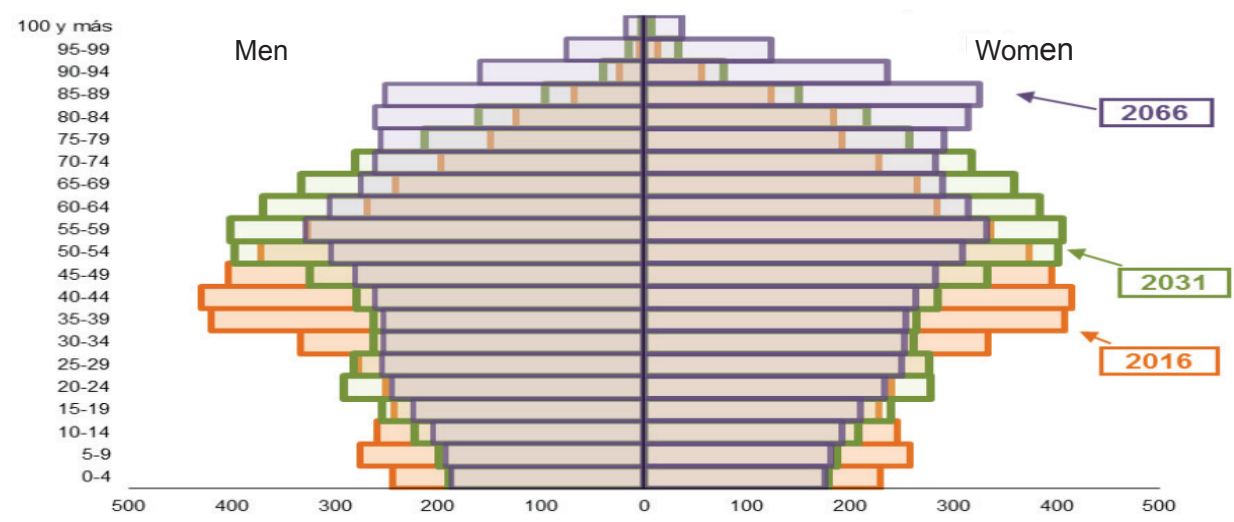

Source: Spanish Statistic Institute (INE, 2016). 


\subsection{Changes within the family structure and informal care}

Along with demographic changes, alterations within the traditional or informal care model, and the growing idea of personal care as social risk, have led to the Spanish WS to build up this new branch of social protection. The former care system has traditionally been based on the unpaid informal work of women carers, which is socially hardly valued. This model of informal care has transformed in the last years; first, in the Nordic social welfare regimes (70s and 80s), then in the continental countries (from the 90s on); finally, the Southern European countries are incorporated to these dynamics, converting an individual into a social risk. This change of model has meant a relative defeminisation of the burden of care, and of opportunity costs as a reflection of the overall women integration into the labour market. The traditional Spanish LTC model has abruptly changed due to the coincidence of the rapid ageing population and the increasing incorporation of women into the labour market, as well as profound alterations within family roles (Rodríguez Rodríguez, 2005). This change is not only based on gender, but also on social differentiation, since it is middle-class working women who have driven the change by buying care services from other working women (especially immigrant) on the market (Bettio, Simonazzi, \& Villa, 2006; Rodríguez Cabrero, 2007).

\subsection{Financial and economic pressures}

Spain has been one of the strongest European countries stricken by the economic crash. During the period 2000-08 the Spanish economy boasted a spectacular growth, because of the building industry and the housing prices, stemming from low interest rates and long-term mortgages (Carreras \& Tafunell, 2010; Sánchez \& García, 2011). With the outbreak of the 2008 economic crisis the country faced a double downturn: the global financial and economic crisis, and the one originated by the real-estate bubble burst. According to OECD, between 2008-10 the GDP slumped -3,42\% and $-0,39 \%$ in 2012 . The labour market was particularly affected by the collapse of the construction sector. In 2013 unemployment topped 26\%. The alleviation of the debt burden to financial entities by the government entailed a public deficit of $11 \%$ in 2009 and a public debt of $118.5 \%$ of GDP in 2014 (Castells, 2014).

As most of the European countries, in the first phase of the crisis 2008-10, and despite the drastic slump of all socioeconomic indicators, the Spanish public social 


\section{The Spanish Long-Term Care System:}

Deployment, Restructuring Processes and Future Challenges

protection expenditure increased from $20 \%$ to $26 \%$ between $2009-11$, respectively (see figure 3).

\section{Figure 3}

Spanish social public spending as a percentage of GDP

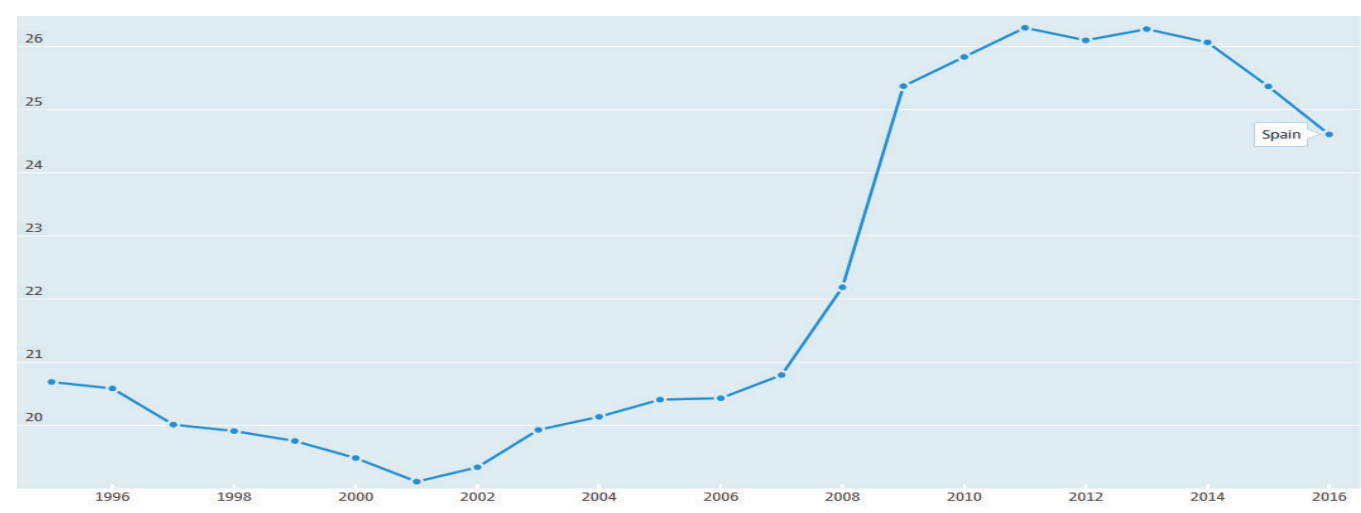

Source: OECD.

As the previous figures show and Vis, van Kersbergen, \& Hylands (2011) also pointed out there was not a major onslaught against neither the European WS nor the Spanish one in the immediate aftermath of the crisis, but quite the opposite: The initial counter policies evolved, generally speaking, more in line with Keynesian intervention and compensation hypothesis rather than a retrenchment and curtailing of the WS (Vaughan-Whitehead, 2015). But the authors warned about the advent of more austerity periods in order to re-establish the balanced budgets lost in the first phases of the crisis. From 2010 on, hefty fiscal consolidation measures to cope with the economic pressures, were put in place and were particularly tangible in countries in which the economic circumstance was worse and labour market pressures were greater (Greve, 2012). In 2011 the Spanish economy slumped into a new recessive period that lasted until 2012. The increasing public deficit compelled the government to announce austerity measures of budgetary control demanded by the European Union. Thus, a phase of austerity began in which social benefits were gradually dismantled, pensions and retirement schemes were put into hold and even reformed in order to increase the retirement age. 


\section{METHODOLOGY}

The methodological approach in this research is the case study analysis which includes a mix of quantitative-qualitative techniques. The analysis of LTC changes and restructuring processes is mainly conducted within three analysis levels: the public services provision; legislative reforms; the social and institutional impact of the economic crisis according to the interviews conducted to key informants which extended to front-line professionals and managers (see Appendix details about the participants profile, institution and sector). The empirical study also includes an overview of indicators, such as the elderly population across OECD countries, the structure of population by age, life expectancy at birth and aging population in Spain (INE). In the first analysis level, quantitative indicators such as: variability of workers within the public LTC sector, and beneficiaries of residential and home-care services between 2009-16 (last data available during the study) are scrutinised. The data include workers affiliated to Social Security according to OECD database and Spanish Social Security Treasury and who work in the realms of people affected by any kind of disability and elderly dependents (these databases are listed in the reference). The shortage of data hindered to include a greater number of indicators. Unlike the first analysis level (which only allows to approach the object of study from a general perspective) the second and third analysis levels, of qualitative nature, enable to deepen into the detection of changes within the institutional and formal settings (legislative changes) as well as in their application within the care field (according to key informants). The legislative reforms examined and implemented in the wake of the 2008 economic crisis until 2017 are: The Royal Decree-Law (RD-L) 8/2010 of Adoption of Extraordinary Measures for the Reduction of the Public Deficit; the RD-L 20/2011 of Urgent Measures in Budget, Tax and Financial Subjects for the Correction of the Public Deficit; and RD-L 20/2012 of Measures to Guarantee the Budgetary Stability, and of the Promotion of Competitiveness.

The revision of changes is focused on four dimensions and ensuing categories: (a) Natural and principles: refers to the changes undertaken amidst the conditions of access to social protection (universal, contributory or assistance-based). The principles (elements that guide public actions) analysed are community care, prevention, equality and quality. (b) Access procedure and recognition of rights: In this dimension the referring changes within all formal procedures related to LTC access from the beginning to the end have been scrutinised in light of ensuing categories: Waiting 


\section{The Spanish Long-Term Care System:}

\section{Deployment, Restructuring Processes and Future Challenges}

lists or time that individuals have to wait to be assessed in order to be eligible to the dictates of official bodies, or to obtain economic benefits and services. These changes in the access may also arise due to the tightening of the eligibility criteria and the modification of the care needs assessment scale that makes, more or less, accessible the entrance to the system. (c) Services provision: It implies changes in the provision of community (day care and home-care) and residential services, and categories such as: the lack of services provisioning; restrictions in the access to certain services, as for instance, residential ones; changes within the assistance models; downgrading of the quality of services or the predominance of one provisioning over others. (d) Organisation, management and funding: The analysis of changes in this dimension encompasses global system financing, privatisation or outsourcing processes, changes in the balance of the contributions between different agents, for example, users' co-payment as well as changes in the labour care market conditions.

Finally, the third level of analysis captures the perceptions of the main actors in the care field related to system deployment, changes, and social and institutional impact of the crisis in the aforementioned dimensions. Semi-structured interview to key informants made out the principal instrument for collating empirical material. A total of 15 semi-structured interviews to key actors, working in the LTC sector, were carried out, along with a sample of participants formed by two types of profiles: frontline professionals (mainly social workers) and managers. The participants' profile had been chosen beforehand in order to ensure maximum diversity of point of views and direct knowledge of the care sector. Based on this criterium, participants linked to the elderly and disability services, both with technical and managers profile, and with dispersed levels of responsibility in the decision-making process, were selected. Social workers were crucial to obtain first-hand information, since they are in charge of care needs evaluation and follow-up of the individual care plan. First contact with the interviewees took place by means of e-mail in September 2017 via a brief professional introductory letter, explaining the objectives of the research, and inviting them to participate. Anonymity and confidentiality were guaranteed. Most of the interviews were conducted in person between September 2017 and February 2018; others, when this was not possible, were carried out by videoconference. Most of the interviews were recorded and transcribed.

Two models of interview-guidance were elaborated as a guide. The scripts were structured in four sections: in the first section the interviewee was asked about his/her professional profile, the job, the running and organisation of the service or the overall 
LTCS functioning, depending on the profile. This first section aims at understanding the interviewees' professional profile and obtaining more accurate knowledge on the LTCS deployment, the service's organisation and functioning. The second section was elaborated according to the dimensions and categories of analysis in order to compile the interviewees' opinion in relation to the changes implemented because of the economic crisis impact. The third section inquired the impact of these alterations on the users. Finally, the questions in the fourth section were designed to explore the reforms' causal or explanatory factors based on the interviewees' perception.

\section{RESTRUCTURING PROCESSES AND DISCUSSION OF CHANGES}

\subsection{Public services provision}

According to OECD database the total number of workers and caregivers in the formal care sector, both in residential and community services, grew unabatedly by $21.7 \%$ between 2009-16, with the exception of the years 2010 and 2011, when it went down $0.5 \%$ and $0.6 \%$, respectively. The total number of beneficiaries of residential care services during the same period increased $77.3 \%$ (going up from 117,346 to 208,108 ) and the number in home-care service peaked $126.8 \%$ (rising from 379,564 to 860,859 ). During the first years of the system implementation, the beneficiaries (recipients) of residential care services increased by almost $40 \%$, and by $50 \%$ of home-care services, respectively. But in 2011 this upward trend came to a halt and even decreased 2\% between 2012-2013.

Nevertheless, from an overview, these indicators demonstrate a straight and widespread LTCS expansion. And on a closer look, a slight decline by $1.1 \%$ between 2010 11. As scholars mentioned in section 2, two phases are distinguishable: A first phase of growth during the crisis's immediate aftermath (2009-10), and a second phase of cutbacks and austerity measures undertaken by the Government between 2010-13. By contrast, despite the steady slump of the social protection expenditure from 2013 onwards (see figure 3), one may perceive a steady increase in the number of workers and recipients within LTC from 2013 on; particularly in terms of recipients at home. This fact is an obvious example of the opposite trend amongst 'the new social risks' represented by Spanish LTC policies, and the 'old social risks' represented by classic WS social policies whose expenditure endured a serious decline after 2013. 


\section{The Spanish Long-Term Care System:}

Deployment, Restructuring Processes and Future Challenges

Another conspicuous tendency since the outset of the LTCS is the predominance of beneficiaries at home over residential recipients (see figure 4). Conversely, the slight rise in residential services and the decline in home-based services between 2011-13, the spectacular growth in home care-services from 2013 onwards is clearly apparent. Thus, the graph plainly shows the expansion of the Spanish LTCS since the application of the LAPAD, and the predominance in the provision of community and domiciliary services over residential services. This can be construed as an unequivocal vocation and commitment towards care within the family environment, and therefore the continuity of a clear-cut family-based model.

\section{Figure 4}

Evolution of recipients at home and in institutions between 2000-16

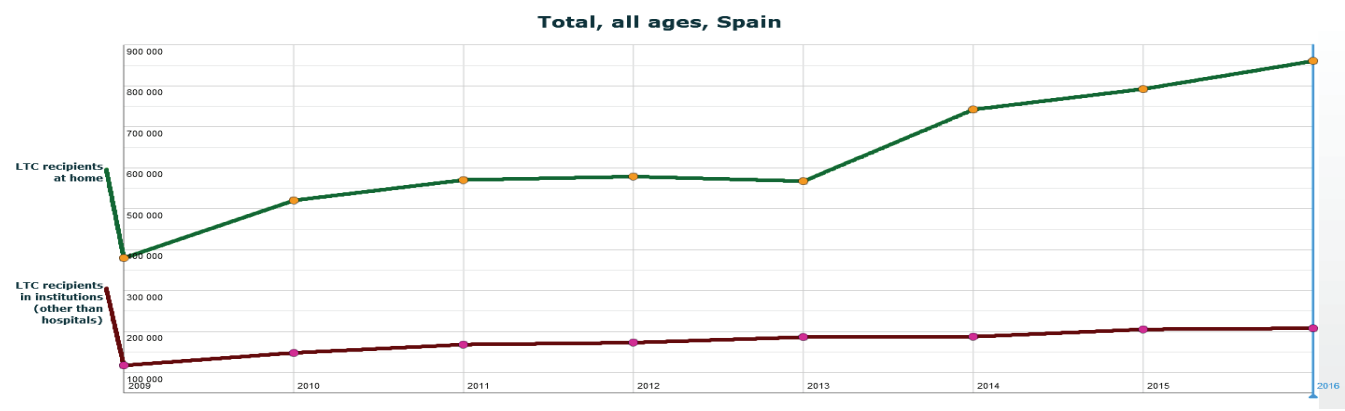

Source: Long-term care recipients (indicator), OECD (2017).

\subsection{Legislative reforms}

The new Spanish care system has been steadily implemented since the coming into force of the LAPAD at the beginning of 2007. This very new system, according to Hall theory (1993), initially implied a paradigmatic or third-order change by means of modifying the basic objectives and principles of the former assistance-based care system (it had been only accessible to people without economic resources) and shifting it into a universal-based system. Yet, the reforms of the Care Act had begun even before it was fully deployed which were taking place between 2010-12, and which were mainly affecting both the 'access procedure and recognition of rights' and 'the provision of services and economic benefits' dimensions. 
Despite the tweaks undertaken within the LAPAD, these did not affect explicitly or directly the 'nature and principles of the system' (first analysis dimension) which would have entailed a third-order change or paradigmatic change (according to Hall); they did so indirectly, for these modifications affected the rights of individuals and prevented people from accessing the system and enjoying their social rights. Even although it was not evident right at the outbreak of the crisis, legislative changes timidly began in 2010 which were justified by the unbalances provoked by the economic crisis. And later on, more acute austerity measures were implemented by means of the Stability and Growth Programme 2012-2015 in order to address Spain's debt and deficit goals.

All amendments towards the Care Act 39/2006 between 2010-12 (RD-L 8/2010 of Extraordinary Measures for the Reduction of the Public Deficit; RD-L 20/2011 of Urgent Measures for the Correction of Public Deficit; RD-L 20/2012 of Measures for Budget Stability and Competitiveness) affected 'the access procedure and recognition of rights' dimension while principally handling three mechanisms: The first geared towards extending time-limit for the recognition of right. Since June 2010 the time-limit to resolve requests for dependency evaluation was extended from three to six months since registration of the application date. Also, the recognition of right was prolonged until the date of resolution, instead of the application date as before. Secondly, delays in the system deployment were extensively applied. In 2011 the implementation of moderate degree (I) of dependence had been deferred for one year, and it was again deferred in 2012. For persons whom had not been granted benefits prior to January 2012, they were not granted until July 2015. The third and last mechanism consisted of tightening access criteria by altering the assessment scale in order to hamper the access to the system. The levels of dependency of each degree were eliminated. Thus, the amount of economic benefits, as well as the hours for homecare services, were downgraded. All these changes prompted a general system retrenchment. In effect and most strikingly, they hindered to satisfy the dependent people's needs. Thus, many of them were left unprotected for years.

Regarding 'provision of services and economic benefits' dimension, the mechanisms which were set up to constrain the system consisted in deferring and suspending the pending payments for non-professional caregivers' benefits (N-PCGB). Meaning that in 2010 the monetary amount pending on payment for 'retroactivity' concept was deferred, and in 2012 a time-suspension for receiving this benefit was established. Furthermore, since 2012 N-PCGB were cut back and suppressed during 2 years in 


\section{The Spanish Long-Term Care System:}

Deployment, Restructuring Processes and Future Challenges

conjunction with the special covenant subscribed to the Social Security for nonprofessional caregivers. The scale assessment modification and the ensuing suspension of dependence levels also implied a 15\% slash of the amount of N-PCGB for both, old and new recipients (see table 2).

\section{Table 2}

Reduction of the N-PCGB by the RD-L 20/2012

\begin{tabular}{ccclc}
\hline Degree/Level & Previously & Afterwards & Degree & Amount \\
\hline III/2 & $520,69 €$ & $442,59 €$ & III & $387,64 €$ \\
III/1 & $416,98 €$ & $354,43 €$ & & \\
\hline II $/ 2$ & $337,25 €$ & $286,66 €$ & II & $268,79 €$ \\
II $/ 1$ & $300,90 €$ & $255,77 €$ & & \\
\hline I/2 & $180,00 €$ & $153,00 €$ & I & $153,00 €$ \\
\hline
\end{tabular}

Source: compiled by the author from the RD-L 20/2012. Economic benefit reduction among the first and second scale previously and afterwards the RD-L 2012.

With the RD-L 20/2012 (see table 3) the reduction of home-care services (HCS) took place. Ever since the monthly hours of HCS were sharply downgraded according to the dependency degree.

\section{Table 3}

Reduction of monthly hours in home-care services since the RD-L 20/2012

\begin{tabular}{ccc}
\hline \multicolumn{2}{c}{ Previously to RD-L 20/2012 } & After the RD-L 20/2012 \\
\hline Degree III & $55-90$ & $46-70$ \\
Degree II & $30-55$ & $21-45$ \\
Degree I & $21-30$ & Max. 20 \\
\hline
\end{tabular}

Source: compiled by the author following the RD-L 20/2012.

Lastly, compatibility between services was also removed when RD-L 20/2012 came into force. From that moment on it was not feasible to perceive more than one service, with the exception of telecare and the HCS. It is worth mentioning that between 2010-14, in some regions, legislative changes relating to the 'organisa- 
tion, management and funding' dimension were undertaken, such as the increase of users' co-payment and the inclusion of users' assets to calculate their co-payment. An economic threshold for being eligible: 19,000€ (degree II) and 24,000€ (degree III) respectively, was established in order to become eligible for economic benefits geared towards the purchase of services. And there was a progressive reduction of the Regions' minimum funding levels by the State as well. Table 4 contains an overview of the most significant legislative changes throughout the scrutinised period.

\section{Table 4}

Legislative reforms in the period 2008-17 following the analytical dimensions

\begin{tabular}{|c|c|c|c|}
\hline Dimensions & $\begin{array}{c}\text { RD-L } \\
8 / 2010\end{array}$ & RD-L 20/2011 & $\begin{array}{c}\text { RD-L } \\
20 / 2012\end{array}$ \\
\hline $\begin{array}{l}\text { - Access proce- } \\
\text { dure and recogni- } \\
\text { tion of the right }\end{array}$ & $\begin{array}{l}\text { - Time-term } \\
\text { extension of the } \\
\text { right recognition. }\end{array}$ & $\begin{array}{l}\text { - Delays in the } \\
\text { system deploy- } \\
\text { ment. }\end{array}$ & $\begin{array}{l}\text { - Delays in } \\
\text { the system } \\
\text { deployment. }\end{array}$ \\
\hline $\begin{array}{l}\text { - Provision of } \\
\text { services and eco- } \\
\text { nomic benefits }\end{array}$ & $\begin{array}{l}\text { - N-PCGB Pay- } \\
\text { ment deferred } \\
\text { for a maximum } \\
\text { period of } 5 \text { years. }\end{array}$ & & $\begin{array}{l}\text { - Tightening the } \\
\text { access. } \\
\text { - N-PCGB } \\
\text { Payment deferred } \\
\text { for } 8 \text { years } \\
\text { - N-PCGB } \\
\text { suspension for } 2 \\
\text { years. } \\
\text { - Reduction of } \\
\text { the N-PCGB and } \\
\text { services. } \\
\text { - Removal of } \\
\text { compatibility } \\
\text { between services. }\end{array}$ \\
\hline
\end{tabular}

- Organisation, management and funding
- Increase of copayment.

- Establishment an economic threshold to receive benefits. - Reduction of regional funding by the Central Government.

Source: compiled by the author according to the legislative reforms. 


\section{The Spanish Long-Term Care System:}

Deployment, Restructuring Processes and Future Challenges

\subsection{Social and institutional impact of the economic crisis}

Most of the interviewees agreed that the Care Act implied a considerable legislative advance in the Spanish social rights for dependants by bringing in the principle of universality within the social services. Likewise, they highlighted that the restructuring processes applied, even before having completely unfolded the system, made this principle impossible to implement. The reason was that contractions prompted the ineffective coverage of needs due to cuts, the shortage of public services and the excessive slowness for accessing the system. On top of that, since its incipience, although the law stresses out the promotion of personal autonomy, the system basically focused on the care for dependent situations whilst neglecting the promotion of autonomy and prevention principles. This very negligence of personal autonomy promotion has been one of the most aspects highlighted by the interviewees, especially, by those working in the disability sector.

In relation to the 'access procedure and recognition of the right' dimension, the professionals point out that the removal of the dependence levels since 2012 has had a strong impact on the users. Not only because of the cuts and downgrading in the provision, but also because of the restriction of access to the system through changes applied in the assessment scale. One of the most affected areas by these restrictions was residential services, since only grades II and III are able to access. The original assessment scale, as expressed by one of the persons in charge of the public dependence assessment agency (SEVAD, for its acronym in Spanish), only evaluated whether a person could perform a task and which supports he/she needed to carry this out. Whereas in the updated scale 'frequency' is introduced: when the frequency to carry out a task is low, the item does not score. Thus, the level of dependency is reduced.

In general terms, interviewees sense that at the onset of the system's deployment the care evaluations were comparatively far laxer and tended to grant higher dependency scores. However, gradually the criteria became much more restrictive. These restrictions of access criteria and assessment scale also exerted a direct impact on the services' providers. A daily centre manager exposed that these kinds of services, characterised by their unambiguous rehabilitation and prevention roles, were compelled to adapt the service with the same economic resources to users with a higher care needs profile, when these restrictions were put into place. A further shortcoming revealed was the unavailability of access due to the waiting lists; above all, in residential services, thus implying that other protection systems were urged to meet the 
care needs. The consequences of the access restrictions compelled dependant people to stay at home over a long period of time, in spite of suffering from a high health deterioration, and consequently, even some of them passed away before receiving the benefits they were entitled to.

Amidst the provisions of services and economic benefits (third analysis dimension), hand in hand with all aforementioned, the historical public services deficit in the Mediterranean Welfare model has induced a deviation towards the cash benefits provision via N-PCGB instead of services since the Law's inception. In light of the services' shortfall, a low care-cost coverage was promoted by the enlargement of this N-PCGB which incentivised care within the family environment (care in place) and reinforced so the family-based nature of the system and its re-familiarisation. It prompted the emergence of new strands of caring within the informal market economy composed by migrant women, too.

Those families who failed to take care of their dependent relatives spend that allowance for buying care in this informal market where labour is cheaper than in the formal sector. Payments' suspension of the caregivers' Social Security also entailed a significant loss of rights, and forced some of the family members to return to the labour market and to assume the double role of worker-caregiver with its ensuing increase in physical and emotional overload. The introduction of the cash benefits for services caused a system's re-commodification as a consequence of the promotion of the private sector by the public bodies. This re-commodification process is also made visible through the strategies employed by the Administration which accredited and granted private entities to provide services.

Regarding the fourth-dimension, interviewees hallmark the precarious system organisation and planning already at the beginning of its deployment in 2007. The shortness of foresight for the needs of dependent people, coupled with the shortage of material and technical resources, led to a chaotic situation during its implementation which lasted until 2012. Concerning the financing, the progressive downgrading in funding from the central Government since 2010 generated a high indebtedness of the Regions, because these had to bear the full weight of the system financing.

The growing tendency towards outsourcing the management and replacing the concept of 'network of public services' with that of 'network of publicly financed services' has also been pointed out. This involves an evident shift inside the management of care services in favour of the profit sector, and hence a re-commodification of the system. Many veteran entities from the non-profit sector, which have been 


\section{The Spanish Long-Term Care System:}

Deployment, Restructuring Processes and Future Challenges

managing care services for years, lose out when a public tender is opened, because private entities offer much more competitive prices in spite of the downgrading of the care services delivered. Since 2012, in some Regions, there has been an upgrading of the user's co-payment, especially within the realm of people with disability. The social workers consider this fact utterly unfair, because co-payments are made by the people with disabilities, and these are pretty high and poorly tailored to their social integration needs.

\section{CONCLUSIONS}

Despite the fact that Spain's ageing population is one of the highest inside the EU, its LTCS is relatively new compared to other European countries. The reasons therefore have been historically attributed to the high solidarity among family members. This has contributed to shape a LTC policy focused on scarce cash transfers, geared towards the reinforcement of family care commitments, and which was labelled by some scholars as implicit family-based care model (Leitner, 2003). Initially, the enactment of the LAPAD 39/2006 implied, from a theoretical standpoint, a genuine 'paradigmatic change' or 'third-order change' by means of modifying the nature and goals of the former care policy (Hall, 1993). On the basis of Esping-Andersen (1990) modelling, it meant a shift from an 'assistance-based' care, centred on the poorest and with a high level of family burden (characteristic of a 'non-caring state regime'), towards a 'universal-based model' (or 'universal care regime') in which the state provides care to all needy persons, thus releasing family members from the burden of caring (Daly \& Lewis, 2000).

But while it is true that the development of the LAPAD clashed head-on with the financial and economic crisis in 2008, according the interviewees the organisational and financial weaknesses of the system were evident from the start when it had been put in place. Despite the fact that all statistical indicators analysed display a considerable increase during almost the entire period, they fail to capture, in detail, the system's evolvement. Although, in truth, there was a relative growth compared to the high level of care needs of the dependant population. During the period analysed two phases or a double process of implementation-expansion (2008-10) and restructuring-retrenchment (2010-17) can be distinguished.

In the first phase of implementation-expansion, even although there is a, more or less, general augmentation in the three analysis levels, the system 's shortcomings 
became obvious in terms of a lack of economic resources, and organisational issues. As early as from this first stage of development, the deficit in resources led to delays inside the assessment of dependency and the procedures for accessing rights. The scarcity of public services, both in the community and institutional setting, entailed a deviation towards cash benefits provision for carers. Hence, it could be claimed that this focus on cash benefits provision and re-orientation of care towards the family environment would have implied a reinforcement of the former system's familybased nature. As Pavolini \& Ranci (2013) also pointed out, it would have also meant a re-familiarisation of the system by transferring the responsibility of care to the family setting.

In the second phase of restructuring-retrenchment, the types of changes implemented corresponded with first and second-order changes. As already mentioned, the mechanisms applied to downsize the system were mainly centred on: restricting the access criteria by means of restricting the assessment scale; delaying the system's deployment in terms of the access to the rights; and curtailing the provision of services and payment of cash benefits. On the other hand, the main restructuring processes applied by the Administrations was cost-containment for reducing the public debt and deficit. All these instruments were implemented in order to downsize the LTCS. And, even although the first and second-order changes are not directed to alter the main objectives of the system's 'paradigmatic change', these very changes hindered the new system to meet such goals.

Thus, the widespread cash-benefits have entailed a re-familiarisation and a re-commodification of the new Spanish LTCS. Its generalisation of the cash benefits also contributed to the proliferation of an unregulated care market, composed of female migrant workers who work full-time and cohabit inside the family. Furthermore, the cost containment process implied a reduction of the entries into institutions, or 'de-institutionalisation' whilst putting the emphasis of the care on the community and family rather than on the institutions, thus lowering the cost of care, as defended by some scholars.

In general terms, it is evident that the expectations, raised by the new universalbased LTCS on a subjective right, have not been fulfilled. In practice, from the start the initial hiccups in the development and the shortage of resources throughout the system 's deployment brought about the ineffectiveness of the actual implementation of the principles and rights upheld by the Law. Already during the implementation phase, organisational problems and the shortage of resources impeded the cover- 


\section{The Spanish Long-Term Care System:}

Deployment, Restructuring Processes and Future Challenges

age of the real needs of dependent people. The endemic provision of public services (a feature of the Spanish WS) grants the system a clear market and familiar-based focus, as a result of the bias in favour of the cash-benefits-centred provision for caring within the family realm. The LAPAD was integrated inside the social services system in which there has traditionally been an important lack of public endowment of resources and services. This shortage, along with the outbreak of the crisis, precipitated the restructuring and the cuts of the system, and the inability to meet users' care needs.

Lastly, based on what has been stated so far, the compelling challenges of the Spanish LTCS are to overcome its familiar and assistance-based nature. This is only feasible with a sufficient endowment of economic resources and services to cover the care needs of all dependent people. In order to transcend the family-based tendency of the system, it would be crucial to provide it with a powerful network of high-end public services by means of expanding residential care to those persons who, due to their high levels of dependency or social problems, cannot remain at home. This should go hand in hand with bolstering the community service system. That means: to equip the LTCS with sufficient and professional quality home services. This would imply, both training and improvement of care worker conditions, and to provide the system with a set of procedures which would warrant the quality of care and the rights of dependent people.

\section{REFERENCES}

Anttonen, A., \& Sipilä, J. (2005). Comparative approaches to social care: diversity in care production modes. In B. Pfau-Effinger \& B. Geissler. (ed.), Care and Social Integration in European Societies (pp. 115-134). Bristol: Policy Press.

Jové, E. A. (2020). Impact of the economic crisis and contractions within the European long-term care systems [Manuscript submitted for publication]. Journal of International and Comparative Social Policy (date of acceptance, December 3rd 2020. Pending of publication).

Bettio, F., \& Plantenga, J. (2004). Comparing care regimes in Europe. Feminist Economics, 10(1), 85-113. 
Bettio, F., Simonazzi, A., \& Villa, P. (2006). Change in Care Regimes and female migration: the 'care drain' in the Mediterranean. Journal of European Social Policy, 16(3), 271-285.

Carreras, A., \& Tafunell, X. (2010). Historia Económica de la España contemporánea (1978-2009). Barcelona, Spain: Crítica.

Castells, M. (2014). La crisis económica europea: una crisis política. EuropeG. http:// www.europeg.com/es/actualidad/noticias? start $=30$

Consejo de Europa. (1998). Recomendación No R. (98)9 del Comité de Ministros a los Estados Miembros relativa a la dependencia. http://envejecimiento.csic.es/ documentacion/biblioteca/registro.htm?id=51023

Council of the European Union. (2003). Joint report by the Commission and the Council on supporting national strategies for the future of health care and care for the elderly. http://ec.europa.eu/employment_social/soc-prot/healthcare/ elderly_en.pdf

Council of the European Union, European Parliament and European Commission (2017). European Pillar of Social Rights. https://ec.europa.eu/commission/sites/ beta-political/files/social-summit-european-pillar-social-rights-booklet_en.pdf

Da Roit, B., \& Le Bihan, B. (2010). Similar and yet so different: Cash-for-care in six European countries' long-term care policies. The Milbank Quarterly, 88(3), 286-309.

Daly, M. (2012). Making Policy for Care: Experiences in Europe and its implications for Asia. International Journal of Sociology and Social Policy, 32(11/12), 623-635.

Daly, M., \& Lewis, J. (2000). The concept of social care and the analysis of contemporary welfare states. British Journal of Sociology, 51(2), 281-298.

Decree 142/2010, $\$ 5738$, (2010, October 11). Approves the Social Services portfolio 2010-2011. https://portaldogc.gencat.cat/utilsEADOP/PDF/5738/1610152.pdf

Deusdad, B., Comas-d'Argemir, D., \& Dziegielewski, S. (2016). Restructuring Longterm care in Spain: the impact of the economic crisis on social policies and social practice. Journal of Social Service Research, 42(2), 246-262. 


\section{The Spanish Long-Term Care System:}

\section{Deployment, Restructuring Processes and Future Challenges}

Deusdad, B., Lev, S., Pace, Ch., \& Vell, S. (2017). Care for older people in three Mediterranean countries: discourses, policies and realities of de-institutionalisation. In Social Services disrupted. Implications and challenges for a crisis-ridden Europe. London. UK: Edward Elgar publishers.

Esping-Andersen, G. (1990). The three worlds of welfare capitalism. Princeton: Princeton University Press.

Esping-Andersen, G. (2000). Fundamentos sociales de las economías postindustriales. Barcelona: Arial.

European Commission. (2007). Comunicación de la Comisión al Consejo, al Parlamento Europeo, al Comité Económico y Social Europeo y al Comité de las Regiones.

Ferrera, M. (1996). The 'Southern Model' of welfare in social Europe. Journal of European Social Policy, 6(1), 17-37.

Flaquer, L. (2002). Familia y estado de bienestar en la Europa del sur. In L. Flaquer. (ed.) Políticas familiares en la Unión Europea (pp. 175-208). Barcelona, Spain: ICPS.

Greve, B. (2012). Editorial Introduction: Overview and conclusion. In B. Greve. (ed.). The Times They Are Changing? Crisis and the Welfare State (pp. 1-6). Oxford: Wiley-Blackwell.

Hall, P. (1993). Policy paradigm, social learning and the state: The case of economic policy in Britain. Comparative Politics, 25(3), 275-296.

Institute for the Elderly and Social Services (IMSERSO). (2005). White Paper on Care of Dependency. https://www.imserso.es/InterPresent2/groups/imserso/ documents/binario/libroblanco.pdf

Institute National Statistic (INE). (2016). Projection of the Spanish population by age group and from 2031 and 2066. Press Releases. https://www.ine.es/prensa/ np994.pdf

INE (2020a). Life expectancy at birth by sex indicator. Retrieved December 12, 2020 from https://www.ine.es/jaxiT3/Datos.htm?t=1414\#!tabs-tabla 
INE (2020b). Population Structure Indicators. Retrieved December 12, 2020 from https://www.ine.es/jaxiT3/Tabla.htm?t=1488

Kodate, N., \& Timonen, V. (2017). Bringing the Family in through the Back Door: the Stealthy Expansion of Family Care in Asian and European Long-Term Care Policy. J Cross Cult Gerontol 32, 291-301.

Care Act 39/2006. (2006, 14th December). Promotion of Personal Autonomy and Care for Dependent Persons. Jefatura del Estado. BOE No 299, BOE-A-200621990. http://dixit.gencat.cat/ca/detalls/Article/20061214LLEI392006

Leitner, S. (2003). Varieties of familism: The caring function of the family in comparative perspective. European Societies, 5(4), 353-375.

Marbán, V. (2012). Actores sociales y desarrollo de la ley de dependencia en España', Revista Internacional de Sociología, 70(2), 375-398.

Martínez, R. (2006). El cuidado de ancianos: Un nicho laboral para mujeres inmigrantes y un reto de gestión para las entidades del tercer sector. Revista Española del Tercer Sector, (4), 145-173.

Organisation for Economic Co-operation and Development (OECD). (2011). Help wanted? providing and paying for long-term care. Paris: OECD. https://doi. org/10.1787/9789264097759-en

OECD (2017). Social spending (indicator). http://doi.org/10.1787/7497563b-en (accessed August 9, 2017).

OECD (2017). Long-term care recipients (indicator). Retrieved October 28, 2017 from https://stats.oecd.org/Index.aspx?DataSetCode=HEALTH_LTCR OECD

OECD (2019), Life expectancy. Society at a Glance 2019: OECD Social Indicators, OECD Publishing, Paris. https://doi.org/10.1787/5d08dbc5-en

OECD (2020), Elderly population (indicator). https://doi.org/10.1787/8d805ea1-en

Oso, L., \& Parella, S. (2012). Inmigración, género y mercado de trabajo: Una panorámica de la investigación sobre la inserción laboral de las mujeres inmigrantes en España. Cuadernos de Relaciones Laborales, 30(1), 11-44. 


\section{The Spanish Long-Term Care System:}

\section{Deployment, Restructuring Processes and Future Challenges}

Österle, A. \& Rothgang, H. (2010). Long-Term Care. In F.G. Castles, S. Leibfried, J. Lewis, H. Obinger, \& C. Pierson (eds), The Oxford Handbook of the Welfare State. https://doi.org/10.1093/oxfordhb/9780199579396.003.0026

Pavolini, E., \& Ranci, C. (2008). Restructuring the Welfare State: Reforms in longterm care in Western European countries. Journal of European Social Policy, 18(3), 246-259.

Pavolini, E., \& Ranci, C. (2013). Reforms in long-term care policies in Europe: An introduction. In C. Ranci \& E. Pavolini (Ed.), Reforms in long-term care policies in Europe (pp. 3-22). New York: Springer.

Pierson, P. (2001). Coping with permanent austerity, Welfare State restructuring in affluent Democracies. In the New Politics of the Welfare State (pp. 410-456). Oxford: Oxford University Press.

Rodríguez Cabrero, G. (2007). El marco institucional de la protección social de la dependencia en España. Estudios de Economía Aplicada, (25)2, 341-372.

Rodríguez Cabrero, G. (2009). El desarrollo de la política social de promoción de la autonomía y atención a las personas en situación de dependencia en España (20072009). https://www.researchgate.net/publication/237031975_El_desarrollo_ de_la_politica_social_de_promocion_de_la_autonomia_y_atencion_a_las_ personas_en_situacion_de_dependencia_en_Espana_2007-2009

Rodríguez Cabrero, G. (2011). Políticas sociales de atención a la dependencia en los Regímenes de Bienestar de la Unión Europea, Cuadernos de Relaciones Laborales, 29(1), 13-42.

Rodríguez Rodríguez, P. (2005). El apoyo informal a las personas mayores en España y la protección social a la dependencia. Del familismo a los derechos de ciudadanía. Revista Española de Geriatría y Gerontología (40)2, 5-15.

Royal Decree 174/2011, $\$ 3174$, (2011, February 11). Approves the scale of assessment of the situation of dependency established by Act 39/2006, of 14th December, on the Promotion of Personal Autonomy and Care for Dependent Persons. https:// www.boe.es/diario_boe/txt.php?id=BOE-A-2011-3174 
Royal Decree-Law (RD-L) 8/2010, \$126, (2010, May 24). Adoption of Extraordinary Measures for the Reduction of the Public Deficit. https://www.boe.es/eli/es/ $\mathrm{rdl} / 2010 / 05 / 20 / 8 / \mathrm{dof} / \mathrm{spa} / \mathrm{pdf}$

RD-L 20/2011, $\$$ 315, (2011, December 31). Urgent Measures in Budget, Tax and Financial Subjects for the Correction of the Public Deficit. https://www.boe.es/ boe/dias/2011/12/31/pdfs/BOE-A-2011-20638.pdf

RD-L 20/2012, \$168, (2012, July 13). Measures to Ensure the Budgetary Stability and Promotion of the Competitiveness. https://www.boe.es/boe/dias/2012/07/14/ pdfs/BOE-A-2012-9364.pdf

Sánchez, M. A., \& García, F. (2011). Crisis económicas y cambio institucional en España: de la gran depresión a la crisis de 2008. http://www.ugr.es/ teoriahe/ RePEc/gra/fegper/FEGWP211.pdf

Spasova, S., Baeten, R., Coster, S., Ghailani, D., Peña-Casas, R., \& Vanhercke, B. (2018). Challenges in long-term care in Europe. A study of national policies, European Social Policy Network (ESPN), Brussels: European Commission.

Urgerson, C. (2005). Gender, Labour market and care work in five European Funding Regimes. In B. Pfau-Effinger \& B. Geissler (ed). Care and Social Integration in European Societies. Bristol: Policy Press.

Vaughan-Whitehead, D. (2015). The European Social Model in times of crisis: An overview. In D. Vaughan-Whitehead (ed.) The European Social Model in crisis: Is Europe losing its soul? (pp. 1-65). Geneve: Edward Elgar Publishing and ILO.

Vis, B., van Kersbergen, K., \& Hylands, T. H. (2011). To what extent did the financial crisis intensify the pressure to reform the Welfare State? Social Policy \& Administration, 45(4), 338-353.

World Health Organization (WHO). (2007). Global age-friendly cities: a guide. https://www.who.int/ageing/publications/Global_age_friendly_cities_Guide_ English.pdf?ua=1 
The Spanish Long-Term Care System:

Deployment, Restructuring Processes and Future Challenges

\section{APPENDIX}

\begin{tabular}{|c|c|c|c|}
\hline PARTICIPANTS & PROFILES & INSTITUTIONS & SECTORS \\
\hline \multirow{4}{*}{$\begin{array}{c}\text { FORNT-LINE } \\
\text { PROFESSIONALS }\end{array}$} & $\begin{array}{c}\text { Social workers in care } \\
\text { services }\end{array}$ & Municipal Social Services & Public \\
\hline & $\begin{array}{l}\text { Social worker specialized } \\
\text { in people with disabilities }\end{array}$ & ONCE & Third sector \\
\hline & $\begin{array}{c}\text { Speech therapist } \\
\text { specialising in dementia }\end{array}$ & $\begin{array}{c}\text { Association of Alzheimer's } \\
\text { sufferers in Gavà }\end{array}$ & Third sector \\
\hline & Legal advisor on disability & Full Inclusion-Dincat & Third Sector \\
\hline \multirow{7}{*}{ MANAGERS } & $\begin{array}{l}\text { Residence Director and } \\
\text { President of the ASCAD }\end{array}$ & $\begin{array}{l}\text { Association of Directors of Care } \\
\text { for Dependent Persons } \\
\text { (ASCAD) }\end{array}$ & Third sector \\
\hline & $\begin{array}{c}\text { Responsible for } \\
\text { dependency assessment } \\
\text { services }\end{array}$ & $\begin{array}{c}\text { Badalona Care Services } \\
\text { SEVAD }\end{array}$ & Public \\
\hline & $\begin{array}{l}\text { Responsible for the area of } \\
\text { social welfare }\end{array}$ & ECOM Federation & Third sector \\
\hline & $\begin{array}{l}\text { Responsible for pendency } \\
\text { evaluations }\end{array}$ & $\begin{array}{c}\text { Department of Labour, Social } \\
\text { Affairs and the Family of the } \\
\text { Generalitat }\end{array}$ & Public \\
\hline & $\begin{array}{l}\text { Social worker } \\
\text { reference of dependence }\end{array}$ & $\begin{array}{c}\text { Department of Labour, Social } \\
\text { Affairs and the Family of the } \\
\text { Generalitat }\end{array}$ & Public \\
\hline & Residence manager & Redòs Foundation & Third sector \\
\hline & $\begin{array}{c}\text { Responsible for the care of } \\
\text { people with intellectual } \\
\text { disabilities }\end{array}$ & Full Inclusion - Dincat & Third sector \\
\hline
\end{tabular}

